\title{
SENSORY EVALUATION AND WILLINGNESS TO PAY FOR ORANGE FLESH SWEET POTATO
}

\author{
O.A. ADEBISI ${ }^{1}$, L.O. ADEBISI ${ }^{2}$, I.B. OLATUNJI ${ }^{3}$, T.O. DAODU ${ }^{2}$, \\ A.M. OMOFAIYE ${ }^{1}$, O.A. AKILAPA ${ }^{2}$
}

*E-mail: tobadebisi@gmail.com

Received: Feb. 25, 2019. Revised: Mar. 27, 2020. Accepted: Apr. 06, 2020. Published online: June 5, 2020

\begin{abstract}
This study seeks to assess consumers' awareness, acceptability and willingness to pay for orange flesh sweet potato (OFSP) in Kwara State, Nigeria. Primary data, which was collected with the aid of a structured questionnaire, was used for the study. A three stage sampling procedure was used to select the respondents for the study. A total of 240 households were used for the study. The data collected were analyzed using descriptive statistics, contingent valuation method, logistic regression model and Likert-type scale. Result of analysis revealed $65 \%$ of the respondents were aware of the health benefits of OFSP, $89.3 \%$ of the consumers were most willing to pay above the bid amount for OFSP in the study area. Also, willingness of consumers to pay for OFSP is significantly affected by age of household head, household size, education of household head, bid amount and
\end{abstract}

awareness of the health benefits of OFSP. The constraints to the consumption of orange flesh sweet potato include scarcity of OFSP, technicality of preparation, perishability and the cost of OFSP. The study therefore recommended that the benefits of OFSP over its indigenous counterpart should be more publicized through research institutes, extension agencies, health workers, NGOs and media for the populace to be more aware, which will enhance consumption in order to alleviate vitamin a micronutrients deficiency. Also, OFSP should be made available at reasonable prices, given that bid amount could dissuade consumers who are interested.

Keywords: vitamin $A$; orange fleshed sweet potato (OFSP); contingent valuation method (CVM); health benefits.

\footnotetext{
${ }_{1}^{1}$ Department of Agricultural Economics and Farm Management, University of llorin, Nigeria

${ }^{2}$ General Management Division, Agricultural Development Management Department, Agricultural and Rural Management Training Institute (ARMTI) Ilorin, Nigeria

${ }^{3}$ Agricultural Finance and Rural Credit Division, Agricultural Development Management Department, ARMTI llorin, Nigeria
} 


\section{INTRODUCTION}

Vitamin A deficiency (VAD) is one of the most prevalent problems in lower-income countries, the most common cause of childhood blindness in the world and it affects 250 million preschool children worldwide. Its acute deficiency has very high fatality rates, but even a little deficiency is also associated with the increase in preschooler mortality. Hence, vitamin A malnutrition is a main public health concern of the developing countries and is responsible for millions of deaths annually among the young children (UN, 1997). It is with this, orange flesh sweet potato (OFSP) was developed through fortification of the indigenous variety with micronutrients specifically vitamin A to combat the issue of its deficiency.

Orange flesh sweet potato is an improved variety of sweet potato (Ipomoea batatas) cultivated in tropical and semi-tropical regions of the world for food and source of income especially among the rural dwellers (Adebisi et al., 2015 and Mitra, 2012). It is a staple crop that is high in beta-carotene and provitamin A carotenoid (Timothy et al., 2017; Padmaja, 2009). It is grown in wide range of agro-ecologies and soil types. OFSP is easy to cultivate, it is a crop with immense ability to grow in marginal fields (Afuape, 2014). It can be vegetatively propagated, and has fairly drought resistant ability once established. It has short maturity period, compare to other root and tuber crops. These characteristics make OFSP an excellent food security crop in Sub-Saharan Africa (Low et al., 2007).

Despite the benefits of this staple crop (OFSP) and the ability to combat one of the major vitamin deficiencies, its consumption is still low. Severe studies have been conducted on the production of OFSP, but empirical findings on it consumption is thin. Therefore, this study seeks to assess consumers' awareness, acceptability and willingness to pay for orange flesh sweet potato Kwara State, Nigeria.

The objectives are to: describe the socio-economic characteristics of the consumers; assess the awareness and sources of information of the health benefit of OFSP to the consumers; to assess the perception of consumers on the sensory quality of orange flesh sweet potato, as it affects the consumption of the crop; examine the willingness of the consumers to pay for OFPS; determine the factors influencing the willingness of consumers to pay for the crop, and identify the constraints' to the consumption of the potato variety.

\section{MATERIAL AND METHODS}

\section{Study area}

This research was carried out in Kwara State, Nigeria. The state is located between latitude $7^{\circ} 20^{\prime}$ and $11^{\circ} 05^{\prime}$ north of the Equator, longitude $2^{\circ} 5^{\prime}$ and $6^{\circ} 45^{\prime}$ east of the prime meridian (Ogunlade et al., 2009). The state has a total land area of $32,500 \mathrm{~km}^{2}$, with a population density of $42.5 \mathrm{~km}^{2}$, also comprises of 16 Local 


\section{SENSORY EVALUATION AND WILLINGNESS TO PAY FOR ORANGE FLESH SWEET POTATO}

Government Areas with a total population estimated to be 3,286,171 (KWADP, 2014; National Population Commission, 2016). It also shares boundaries with Oyo, Ondo and Osun to the south, Kebbi and Niger to the north, Kogi to the east and the Republic of Benin to the west (Kwara State Ministry of Information, 2002). Besides, it has two distinct seasons (the wet and dry seasons) and the average daily temperature ranges between $21^{\circ} \mathrm{C}$ to $35^{\circ} \mathrm{C}$. The annual rainfall pattern across the State is between the months of April and October, with annual rainfall ranging between 1,000 and 1,500 $\mathrm{mm}$. The State, which is primarily agrarian, with great expanse of arable land, has an estimated figure of 260,528 farm families, majority of which live in the rural areas and about 36,820 ha of farmland (KWADP, 2014).

\section{Data and sampling techniques}

We adopted a three stage sampling procedure to select the respondents for the study. The first stage involved purpose selection of three local government areas (Edu, Ifelodun, and Patigi), where orange flesh sweet potato is mostly cultivated in Kwara State. The second stage involved the random selection of four communities in each local government. In the third stage, we randomly selected 20 households in each community. The sample consists of 240 farming households. Personal interviews were carried out with the household head, in the presence of other family members. A standardized questionnaire was used to elicit information on socio-economic indices, information on consumer awareness on the health benefits of orange flesh sweet potato, perception of consumer and willingness to pay for orange flesh potato and reasons why consumers may not be willing to pay for it.

\section{Analytical techniques}

\section{Descriptive analysis}

Descriptive statistics comprising of the use of measures of central tendency and dispersion (mean, mode, median and standard deviation), percentages frequency and tabulation was used to capture the socio-economic characteristics of respondents, assess the consumers' awareness of the health benefits of orange flesh sweet potato and the challenges encountered in the consumption of orange flesh sweet potato.

\section{Contingent valuation method}

The contingent valuation method (CVM) was used to examine consumer's willingness to pay for the new improved variety (orange flesh sweet potato) in the study area. This method is also used to solicit consumers' willingness to pay for a product that is not yet in the market. CVM is a non market valuation method that is used to value specific changes from the obtainable norm. The method relies on directly querying individuals about their willingness to pay (WTP) for a specified improvement in the course of an interview. CVM is a stated preference technique, whereby the individual states his or her preference.

Specifically, in carrying out this technique, individuals were asked about the status quo versus the alternative being proposed and as such information was elicited about the individual's opinion of the alternative relative to what had always existed and the willingness to obtain the proposed alternative. Willingness to pay may specifically be defined as the amount that must be taken away from the person's income, while keeping his utility constant. Willingness to pay may be stated as follows:

$$
V\left(y-W T P, p, q_{1} ; Z\right)=V\left(y, p,, q_{0} ; Z\right)
$$


where, $V$ denotes the indirect utility function, $y$ is income, $p$ is a vector of prices faced by the individual, and $q$ are the alternative levels of the good or 0 or 1 quality indexes (with $q>q$, indicating that $q$ refers to 0 or 1 the improved commodity or value addition). CVM is now increasingly used (Alberini and Cooper, 2000).

\section{Logistic regression model}

The logistic regression model was used to examine the factors influencing the willingness to pay for orange flesh sweet potato among households in the study area. The logistic regression model is specified as:

$$
P_{1}=E\left(y=1 / X_{i}\right)=\beta_{0}+{ }_{i} X i A
$$

where, $X_{i}$ represents explanatory variables included in the model and $y$ is a dichotomous response variable (1 for consumers that are willing to pay and 0 otherwise).

$$
P_{1}=E\left(y=1 / X_{t}\right)=\frac{1}{\left|1+e-\left(\beta_{0}+\beta_{1} X_{1}\right)\right|}
$$

Therefore,

$$
P_{1}=\frac{1}{1+e^{-z_{i}}}=\frac{e^{z_{i}}}{1+E_{z l}}
$$

This is (cumulative) logistic distribution function, where, $Z_{i}=Z_{i}$ ranges from $x P_{i}$ ranges between 0 and $1, P_{i} P$ is nonlinearly related to $Z_{i}$ (i.e. $X i$ ).

$P_{i}=$ Probability of an individual choosing an alternative $i$

$\beta_{0}=$ Constant

$\mathrm{B}_{1} \ldots \mathrm{B}_{8}=$ Coefficient of the explanatory variable $X_{1} \ldots X_{9}$

$y=f\left(X_{1}, X_{2}, X_{3}, X_{4}, \ldots X_{9}, \varepsilon_{i}\right)$

based on the household production framework of Becker (1965) and Strauss and Thomas (1995).

$y=$ willingness to pay (dummy variable); $1=$ consumers willing to pay, $0=$ otherwise); $X_{1}$ - Age (years); $X_{2}-$ Sex (male or female); $X_{3}$ - Marital status; $X_{4}$ Household size (number); $X_{5}$ - Education (years of schooling); $X_{6}$-Household monthly income (Naira); $X_{7}$ - Bid amount; $X_{8}$ - Health awareness; $\alpha$ - Intercept; $\varepsilon_{i}$ Error term, assumed to be uniformly distributed.

\section{The Likert-type scale}

Five-point Likert-type scale was used to assess the perception of consumers regarding the sensory qualities of OFSP. The consumers were asked to rate the perception on a 5 point numerical rating scale of: excellent $=5$, very good $=$ 4, good $=3$, fair $=2$ and poor $=1$.

\section{RESULTS AND DISCUSSION}

\section{Socio-economic characteristics of households}

Table 1 presents the result on the socio-economic characteristics derived from the sampled households. This provides a background to the analysis carried out in this study given that socio-economic characteristics are significant factors that influence consumers' willingness to pay for orange flesh sweet potato. The socioeconomic characteristics revealed that $65 \%$ of the household were headed by male and majority (93.75\%) of them were married. 
The average age of the household heads was 44.8 years, while majority $(69.1 \%)$ of the household heads belonged to age range of 31-50 years, which is an indication that they are in their prime age. The average household size in the study area was 6.33 individuals per households and about (7.5\%) had no formal education. The average monthly income of households in the study area was $19,250(1)=$ 0,0027 \$).

Awareness of consumers on the health benefit of orange flesh sweet potato (OFSP)

Table 2 gives a summary of the level of awareness on the health benefit of OFPS in the study area. Findings from this study revealed that up to $65 \%$ of the respondents were aware of the health benefits of OFSP, stating that they had prior knowledge about OFSP and the inherent benefits to human health. However, $35 \%$ of the respondents stated that they often see the variety of potato, but were not aware that it has more health benefits than the existing potato variety.

\section{Source of information on the health benefits of OFSP}

Table 3 shows the result of consumers' sources of information on the health benefits of OFSP. Many $(64.8 \%)$ of the households attributed their knowledge of the health benefits of the OFSP crop to the farmers planting it and the government agencies promoting it while few (about $6.4 \%$ ) got their information from the media (radio and television). This implies that OFSP crop still needs to be more publicized for the benefit of the populace, especially households having younger children.

Perception of consumers on the sensory quality of OFSP

The result in Table 4 shows the perception of consumers regarding the sensory qualities of OFSP. The households' opinion on the taste, texture and tenderness of OFSP was said to be excellent, while the colour was said to be very good and the smell was said to be good. On the ranking of the sensory qualities, the tenderness ranked $1^{\text {st }}$, while the smell ranked $5^{\text {th }}$.

\section{Maximum amount consumers are willing to pay for OFSP}

In analyzing the willingness to pay for OFSP, the bid amount used in this study was set at the sale price of the counterpart variety which was already in the market. The results of the willingness to pay in Table 5 revealed that consumers were most willing to pay for OFSP in the study area with $63.2 \%$ willing to pay $20 \%$ premium above price of the indigenous counterpart. With an increase in premium to $30 \%$, up to $26.1 \%$ of the consumers were willing to pay for OFSP, while $10.7 \%$ of the households were willing to pay for OFSP at a premium of $20 \%$ below the conventional price, which may be due to not knowing the value and importance of the crop. 
O.A. ADEBISI, L.O. ADEBISI, I.B. OLATUNJI, T.O. DAODU, A.M. OMOFAIYE, O.A. AKILAPA

Table 1 - Distribution of respondents according to their socio-economic characteristics

\begin{tabular}{|c|c|c|}
\hline Characteristics & Frequency $(\mathrm{N}=240)$ & Percentage (100\%) \\
\hline \multicolumn{3}{|l|}{ Gender } \\
\hline Female & 84 & 35.0 \\
\hline Male & 156 & 65.0 \\
\hline \multicolumn{3}{|l|}{ Age } \\
\hline$\leq 30$ & 12 & 05.0 \\
\hline $31-40$ & 88 & 36.6 \\
\hline $41-50$ & 78 & 32.5 \\
\hline $51-60$ & 27 & 11.3 \\
\hline$>60$ & 35 & 14.6 \\
\hline Mean age & 44.38 & \\
\hline \multicolumn{3}{|l|}{ Marital status } \\
\hline Single & 15 & 06.25 \\
\hline Married & 225 & 93.75 \\
\hline \multicolumn{3}{|l|}{ Educational level } \\
\hline No formal & 18 & 07.5 \\
\hline Primary & 75 & 31.3 \\
\hline Secondary & 93 & 38.7 \\
\hline Tertiary & 54 & 22.5 \\
\hline \multicolumn{3}{|l|}{ Household size } \\
\hline$<5$ & 118 & 49.2 \\
\hline $6-10$ & 62 & 25.8 \\
\hline $11-15$ & 38 & 15.8 \\
\hline $16-20$ & 18 & 07.5 \\
\hline$>20$ & 04 & 01.7 \\
\hline Mean household size & 6.33 & \\
\hline \multicolumn{3}{|l|}{ Occupation } \\
\hline Farmers & 108 & 45.0 \\
\hline Civil servants & 35 & 14.6 \\
\hline Artisans & 54 & 22.5 \\
\hline $\begin{array}{l}\text { Traders } \\
\text { Monthly income (Naira) }\end{array}$ & 43 & 17.9 \\
\hline$\leq 10,000$ & 72 & 30.0 \\
\hline $11,000-20,000$ & 80 & 33.3 \\
\hline $21,000-30,000$ & 36 & 15.0 \\
\hline $31,000-40,000$ & 28 & 11.7 \\
\hline $41,000-50,000$ & 14 & 05.8 \\
\hline$>50,000$ & 10 & 04.2 \\
\hline Mean & 19,250 & \\
\hline
\end{tabular}

Source: Field Survey, 2019 


\section{SENSORY EVALUATION AND WILLINGNESS TO PAY FOR ORANGE FLESH SWEET POTATO}

Table 2 - Consumer's awareness of the health benefits of orange flesh sweet potato (OFSP)

\begin{tabular}{lcc}
\hline Awareness & Frequency & Percentage \\
\hline Aware & 156 & 65.00 \\
\hline Unaware & 84 & 35.00 \\
\hline Total & 240 & 100 \\
\hline
\end{tabular}

Source: Field survey, 2019

Table 3 - Consumer's source of information on the health benefit of OFSP

\begin{tabular}{lcc}
\hline Source & Frequency $(\mathbf{N}=\mathbf{1 5 6 )}$ & $\begin{array}{c}\text { Percentage } \\
\mathbf{( 1 0 0 \% )}\end{array}$ \\
\hline Radio and television & 10 & 06.4 \\
\hline Farmers & 55 & 35.3 \\
\hline Government agencies & 46 & 29.5 \\
\hline Extension officers & 20 & 12.8 \\
\hline Friends and family & 25 & 16.0 \\
\hline
\end{tabular}

Source: Field survey, 2019

Table 4 - Consumer's perception on the sensory quality of OFSP

\begin{tabular}{lcccccccc}
\hline $\begin{array}{l}\text { Sensory } \\
\text { qualities }\end{array}$ & Excellent & $\begin{array}{c}\text { Very } \\
\text { good }\end{array}$ & Good & Fair & Poor & Total & $\begin{array}{c}\text { Mean } \\
\text { rating }\end{array}$ & Rank \\
\hline Taste & 525 & 208 & 147 & 62 & 3 & 945 & 3.94 & $2^{\text {nd }}$ \\
\hline Texture & 275 & 188 & 345 & 36 & 5 & 849 & 3.54 & $4^{\text {th }}$ \\
\hline Colour & 205 & 408 & 258 & 22 & 0 & 893 & 3.72 & $3^{\text {rd }}$ \\
\hline Tenderness & 550 & 272 & 150 & 24 & 0 & 996 & 4.15 & $1^{\text {st }}$ \\
\hline Smell (aroma) & 290 & 240 & 225 & 92 & 1 & 848 & 3.53 & $5^{\text {th }}$ \\
\hline
\end{tabular}

Source: Field survey, 2019

Table 5 - Willingness to pay for OFSP by consumers

\begin{tabular}{lcc}
\hline WTP & Frequency & $\begin{array}{c}\text { Percentage } \\
\text { (100\%) }\end{array}$ \\
\hline $\begin{array}{l}\text { Willingness to pay 20\% below cost of orange flesh sweet } \\
\text { potato }\end{array}$ & 25 & 10.7 \\
\hline $\begin{array}{l}\text { Willingness to pay 20\% above cost of orange flesh sweet } \\
\text { potato }\end{array}$ & 148 & 63.2 \\
\hline $\begin{array}{l}\text { Willingness to pay 30\% above cost of orange flesh sweet } \\
\text { potato }\end{array}$ & 61 & 26.1 \\
\hline
\end{tabular}

Source: Field survey, 2019; Bid price $=\# 170$ per kg

Factors influencing the willingness of consumers to pay for OFSP in the study area

The result of the analysis carried out to identify the factors influencing the willingness of consumers to pay for OFSP in the study area, as presented in Table 6, revealed coefficient of determination $\left(\mathrm{R}^{2}\right)$ of $58.9 \%$; hence, showing the variables included in the model adequately explains the willingness to pay by the consumers. Likewise, the observed $\log$ likelihood value, which was 
negative and close to zero, is an indication that the model is a good fit.

Binary logistic regression model reveals that willingness of consumers to pay for OFSP in the study area is significantly affected by age, household size, education of household head, bid amount and awareness of the health benefits of OFSP.

The coefficient of age was found positive and significant at $10 \%$ implying that older household heads are more willing to pay for OFSP, which may be due to the fact that older people shows more interest in what they and their households consume when compared with the younger ones. This result is in alignment with the findings of Haghjou et al. (2013) in a study carried out to determine factors influencing willingness to pay for organic food products in Tabriz, Iran.

The coefficient of education of household head was positive and significant at 5\%, which implies that the more educated a household head, the more willing to pay for OFSP, this may be due to the fact that more educated people are more aware of the importance of improved crops. This result is however at variance with the study carried out by Ghorbani and Hamraz (2009) in Iran, where they found negative relationship between willingness to pay and educational level, which may be due to certain peculiarities in their country. The coefficient of household size was negative and significant at $10 \%$, which implies the lesser the number of household members, the more the willingness to pay for OFSP in the study area, this might be because increase in household size would increase household spending on OFSP, which households might not be able to afford thus explaining for the decrease in their willingness to pay for such.

The coefficient of bid amount was negative and significant at $5 \%$, which implies the lesser the bid amount of OFSP, the more the willingness to pay for OFSP in the study area, this might be because households prefer cheaper things especially food items, so as to reduce their food expenditure, which mostly occupies more than $50 \%$ of an household expenditure. This finding is in line with those of Owusu and Anifori (2013), Obayelu et al. (2014) and Adekunle et al. (2016) bids was found to influence willingness to pay for organic leafy vegetables in Oyo and Ogun States.

The coefficient of awareness of health benefit was positive and significant at $10 \%$, which implies the more households are aware of the health benefits of OFSP, the more their willingness to pay for OFSP in the study area, this might be because knowing the health benefits of a product aids its consumption, which on the long run increases the demand for it.

These findings are in tandem with those of Owusu and Anifori (2013), Obayelu et al. (2014) and Adekunle et al. (2016), where awareness and safety were found to 
influence willingness to pay for organic leafy vegetables in Oyo and Ogun States.

Variables, such as gender of household head, marital status and income, were not significant in explaining the factors influencing the willingness of consumers to pay for OFSP in the study area.

\section{Constraints to the consumption of OFPS}

The results in Table 7 present the constraints to the consumption of OFSP. Scarcity of OFSP ranked the first constraint while the other constraints include technicality of preparation, perishability and the cost of OFSP.

Table 6 - Logit regression result of factors influencing WTP

\begin{tabular}{lccc}
\hline Variables & Coefficient & Standard Error & t-value \\
\hline Age & $0.055775^{*}$ & 0.029477 & 1.89 \\
\hline Gender & 0.37643 & 0.3359452 & 1.12 \\
\hline Marital status & 0.1699772 & 0.2270408 & 0.75 \\
\hline Household size & $0.1549719^{*}$ & 0.0861001 & 1.80 \\
\hline Education & $0.0681132^{* *}$ & 0.1741855 & 2.39 \\
\hline Monthly income & 0.0030984 & 0.0073681 & 0.42 \\
\hline Bid amount & $0.0634621^{* *}$ & 0.0301362 & 2.11 \\
\hline $\begin{array}{l}\text { Awareness of OFSP health } \\
\text { benefits }\end{array}$ & $1.605967^{*}$ & 0.9332723 & 1.72 \\
\hline Constant & 0.9368333 & 1.328922 & 0.70 \\
\hline
\end{tabular}

Source: Field survey, 2019; ** Significant at 5\%, *Significant at 10\%. Number of observation $=240 ;$ LR chi $^{2}(9)=11.90 ;$ Prob> chi $^{2}=0.0000$; Log likelihood $=147.43841$ and Pseudo $\mathrm{R}^{2}$ $=0.5891$

Table 7 - Constraints to consumption of OFSP

\begin{tabular}{lccc}
\hline Constraints & Frequency $(\mathbf{N}=\mathbf{2 4 0})$ & Percentage (100\%) & Rank \\
\hline Cost of OFSP & 16 & 06.7 & $4^{\text {th }}$ \\
\hline Scarcity & 102 & 42.5 & $1^{\text {st }}$ \\
\hline Technicality of preparation & 84 & 35 & $2^{\text {nd }}$ \\
\hline Perishability & 38 & 15.8 & $3^{\text {rd }}$ \\
\hline
\end{tabular}

Source: Field survey, 2019

\section{CONCLUSIONS AND RECOMMENDATION}

The study concluded that there is significant knowledge on the health benefits of OFSP among consumers in Kwara State and that there is demand for it provided the amount they are willing to pay. However, there is still shortage in the supply of OFSP given that not all farmers are planting it and those planting have not fully maximize it. Thus, consumers were unable to access OFSP in the study area. The study therefore recommends that the benefits of OFSP over its indigenous counterpart should be more publicized through research 
institutes, extension agencies, health workers, NGOs and media. This will increase the awareness of the people, enabling them to consume more of OFSP thereby alleviating micronutrients deficiency (vitamin A). Also, farmers should be encouraged to plant OFSP by giving them subsidized materials and inputs, especially OFSP vines, so that supply can meet with demand of consumers. It is also recommended that OFSP should be made available at reasonable prices given that bid amount could dissuade consumers who are interested.

\section{REFERENCES}

Adebisi, B.A., Phorbee, O.O., Chima, B.N., Njoku, J.C., Iheonu, M.E., Adegoke, A.A., Chima, I.P., Low, J.W. \& Mbabu, A.N. (2015). Orange-fleshed sweet potato: production, processing and utilization. A community Training Manual. Helen Keller International, Nigeria and International Potato Center, Nigeria.

Adekunle, C.P., Akerele, D., Adekunle, A.K. \& Amodemaja, T.S. (2016). Consumers' willingness to pay for organic leafy vegetables in Abeokuta Southwest Nigeria: evidence from double bounded dichotomous choice approach. Nigerian Journal of Agriculture, Food and Environment, 12 (1): 17- 23.

Afuape, S.O., Nwankwo, I.I.M., Omodamiro, R.M., Echendu, T.N.C. \& Toure, A. (2014). Studies on some important consumer and processing traits for breeding sweet potato for varied end-uses. J.Exp. Agric., 4(1): 114-124, DOI: 10.9734/AJEA/2014/5827

Alberini, A. \& Cooper, J. (2000). Application of contingent valuation method in developing countries. Economic and social development paper, No. 146, FAO, Rome.

Becker, G. (1965). A model of the allocation of time. The Economic Journal, 75(299): 493-517, DOI:10. $2307 / 2228949$

Ghorbani, M. \& Hamraz, S. (2009). A survey on factors affecting on consumer's potential willingness to pay for organic products in Iran (a case study). Trends Agric.Econ., 2(1): 10-16, DOI: 10.3923/tae.2009. 10.16

Haghjou, M., Hayati, B., Pishbahar, E., Mohammadrezaei, R. \& Dashti, Gh. (2013). Factors affecting consumers' potential willingness to pay for organic food products in Iran: case study of Tabriz. J.Agr.Sci. Tech., 15: 191-202.

Kwara Agricultural Development Project (KWADP) (2014). Annual Report, Kwara ADP, Ilorin, Nigeria.

Kwara State Ministry of Information (2002). Kwara State Diary 2002, pp. 1-10.

Low, J., Arimond, M., Osman, N., Cunguara, B., Zano, F. \& Tschirley, D. (2007). A food based approach introducing orange-fleshed sweet potatoes increased vitamin $A$ intake and serum retinol concentrations in young children in riral Mozambique. J.Nutr., 137(5): 1320-1327, DOI: 10.1093/jn/137.5. 1320

Mitra, S. (2012). Nutritional status of orange-fleshed sweet potatoes in alleviating vitamin $\mathrm{A}$ malnutrition through a food-based approach. J.Nutr. Food Sci., 2(8), DOI: 10.41 72/2155-9600.1000160.

National Population Commission (2016). Publication of National Population Commission, Abuja, Nigeria.

Obayelu, O.A., Agboyinu, O.M. \& Awotide, B.A. (2014). Consumers' perception and willingness to pay for organic leafy vegetables in urban Oyo State, Nigeria. European J.Nutr. 


\section{SENSORY EVALUATION AND WILLINGNESS TO PAY FOR ORANGE FLESH SWEET POTATO}

Food Saf., 4(2): 127-136, DOI: 10.9734/EJNFS/2014/6498

Ogunlade, I., Oladele, O.I. \& Babatunde, A.O. (2009). Farmers' attitude to beneficiary funding of extension services in Kwara State, Nigeria. J.Hum.Ecol., 26(3): 215-220, DOI: 10.1080/09709274.2009.11906185

Owusu, V. \& Anifori, M.O. (2013). Consumer willingness to pay a premium for organic fruit and vegetable in Ghana. Int.Food Agribus.Man., 16(1): 67-86, DOI: 10.22004/ag.econ.144649

Padmaja, G. (2009). Uses and nutritional data of sweetpotato. In: The Sweetpotato, Chapter 11, pp. 189234, Springer Netherlands, DOI 10.1007/978-1-4020-9475-0_11.

Strauss, J. \& Thomas D. (1995). Human resources: empirical modeling of household and family decisions. In: Behrman, J. and Srinivasan, T.N. (Eds.). Handbook of Development Economics, Elsevier, Amsterdam, 3A, 1883-2023, DOI: 10.1016/s15 73-4471(05)80006-3

Timothy J.B, Frank O., Roger S. \& Lynn B (2017). Promotion of orange flesh sweet potato by demonstration of acceptance and food product development. Afr.J. Food Sci., 11(12), 383-388, DOI: 10.5897/ajfs 2017.1647

United Nations, Administrative Committee on Coordination/SubCommittee on Nutrition (1997). Third report on the world nutrition situation. World Health Organization, Geneva, Switzerland. 